Measurement of

\section{Frost-hardiness in Douglas Fir at Three Nurseries by an Electrical Method}

\section{By R. VAN DEN DRIESSCHE}

Research Division, British Columbia Forest Service, Victoria, B.C.

ODC 181.22

\section{Abstract}

Frost-hardiness changes in three Douglas fir provenances at each of three nurseries were followed from September, 1968, to April, 1969, by measuring electrical impedance of stems. Nursery had a greater effect on hardiness than provenance, with seedlings at one nursery reaching the same level of hardiness two weeks earlier than those at another nursery. Detection of these hardiness differences shows the practical value of the impedance method for measuring frosthardiness.

\section{Résumé}

De l'emploi de l'impédance électrique comme méthode en pépinières pour mesurer la résistance au gel de semis de Sapin de Douglas

De septembre 1968 à avril 1969 , on a observé les variations de la résistance au gel de trois provenances de plants de Sapin de Douglas, à trois pépinières, en mesurant l'impédance électrique sur les tiges. La pépinière produisit plus d'effets sur la robustesse que la provenance; les semis d'une pépinière atteignirent le même niveau de robustesse deux semaines plus tôt que ceux d'une autre. La détection de ces différences de robustesse démontre la valeur pratique de la méthode d'impédance pour mesurer la résistance au gel.

Suitability of conifer nursery stock for planting-out depends on several factors such as size, general state of dormancy, and frost-hardiness. Degree of frost-hardiness is particularly important if seedlings are to be planted at high elevation. Electrical methods have been developed for measurement of frost-hardiness in woody plants (Wilner et al. 1960), and it has been shown that stem impedance is well correlated with frost-hardiness in Douglas fir seedlings (van den Driessche 1969). Work described here was done to determine the practicality of the impedance method, and to see what effect provenance and nursery had on frost-hardiness changes in Douglas fir seedlings.

\section{Methods}

Three 2-0 Douglas fir provenances, representing high, medium, and low elevation sources, were selected at Koksilah, Green Timbers, and Chilliwack nurseries. Only the high elevation provenance (Thurston) was the same at all nurseries. One bed of each provenance was divided into two blocks. Five seedlings were lifted from each block at 14-day intervals from mid-September to early December, 1968, and from late January to late April, 1969. Seedlings were placed in plastic lined paper bags and immediately despatched to the laboratory. The average time elapsing between lifting and measurement was 3 days, and the maximum 7 days. At the laboratory plants were subjected to 16 hours at $-9.5^{\circ} \mathrm{C}$, and then allowed to reach room temperature $\left(25^{\circ} \mathrm{C}\right)$, before two stem impedance measurements were made above the root collar using equipment previously described (van den Driessche et al. 1968). Results were treated by analysis of variance omitting January data because deep snow prevented lifting of Chilliwack samples during this month.

\section{Results and Discussion}

After early October 2-0 Douglas fir plants at Chilliwack were apparently more frost-hardy than plants at Green Timbers or Koksilah, since Chilliwack plants showed higher impedance values which indicate greater frost-hardiness (Fig. 1). The difference between Chilliwack and the other two nurseries was most pronounced during November. In fact the same degree of hardiness was achieved about two weeks earlier at Chilliwack than at Koksilah or Green Timbers. At Koksilah plants did not become quite as frost-hardy during the winter

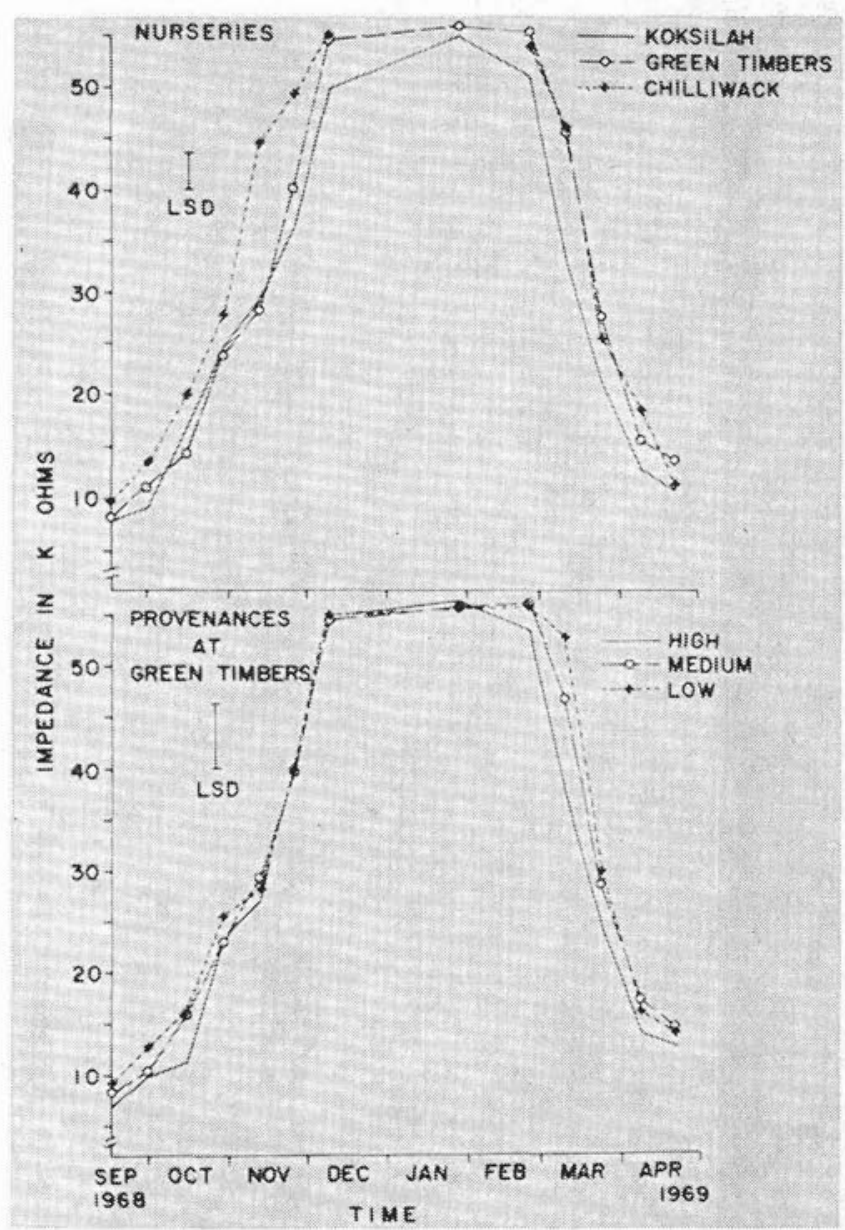

Fig. 1. Effect of nurseries (above) and provenance at Green Timbers nursery (below) on stem impedance. Higher stem impedance values indicate greater frost hardiness. 
as plants at the other two nurseries, and they also lost hardiness earlier in spring.

Provenances did not show significant differences in frost-hardiness. At Green Timbers, however, the data suggested slightly earlier loss of hardiness in the high elevation provenance during spring (Fig. 1.). At Chilliwack there was an indication that the low elevation provenance hardened slightly earlier, and the high elevation provenance slightly later, than the medium elevation provenance during fall.

Earlier development of frost-hardiness at Chilliwack might be expected because this nursery is in a more severe climate than the other two. However, it also has a sandier soil. Weather records from adjacent stations suggest temperature differences did not account for the earlier loss of frost-hardiness at Koksilah than at Green Timbers in spring. For

\section{References}

VAN DEN DRIESSCHE, $R, K, H$ AUSTIN, $M$, B. BALDERSTON and A. G. STEWART, 1968. A portable meter for measuring impedance of tree seedling stems. For. Chron. 44(2):35-36.

VAN DEN DRIESSCHE, R. 1969. Measurement of frost example, the mean monthly minima for the first four months of 1969, appropriate for Koksilah, were 19.2, $27.5,31.6,38.1^{\circ} \mathrm{F}$, and corresponding values for Green Timbers were $22.4,32.0,35.9$, and $41.4^{\circ} \mathrm{F}$.

These results show that stem impedance measurement is a practical way of comparing frosthardiness in conifer seedlings. Apparently development of hardiness in 2-0 Douglas fir is considerably affected by nursery. It is not clear whether climate or some other factor, such as soil, causes the nursery effect. Once the factor is identified, however, time of hardening could be influenced by suitable nursery location.

The assistance of Mr. B. Gibb and co-operation of Reforestation Division, British Columbia Forest Service, in this work are gratefully acknowledged.

hardiness in two-year-old Douglas fir seedlings. Can. Jour. Plant Sci. 49:159-172.

WILNER, J., W. KALBFLEISCH and W. J. Mason, 1960. Note on two electrolytic methods for determining frost hardiness of fruit trees. Can. Jour. Plant Sci. 40:563-565.

\section{New Members}

\section{ACTIVE}

G. E. Boothroyd, 840 Browngate Rd., Richmond, B.C.

W. H. Collins, 358 Broadview, Pembroke, Ont.

Ralph A. Fowler, 105 Seymour St., Kamloops, B.C.

G. M. Gagnon, 1019 Rue Louis-Jobin, Ste. Foy, Que.

A. Lemelin, 917 Place Beloeil \#4 Ste. Foy 10, Que.

Dr. R. P. Pharis, Dept. of Biology, University of Calgary, Calgary, Alta.

George K. Ross, Woodland Section, CPPA,

2300 Sun Life Bldg., Montreal, Que.

A. J. Simard, Forest Fire Research Ins. Dept. Fisheries \& Forestry, Ottawa, Ont.
H. Struik,

Box 60, Suite 7, PR 3

Sudbury, Ont.

R. Y. C. Tay,

c/o District Forest Office

Box 212,

Sandakan,

Sabah, Malaysia

B. N. Ward,

1606 Ayleslynn Drive,

N. Vancouver, B.C.

K. J. Weiss,

B.C. Forest Products Ltd.,

1190 Melville St.,

Vancouver 5, B.C.

O. K. Bradwell,

Ste. 229, 908 Berkley Rd.,

North Vancouver, B.C.

C. Deminger,

Box 280,

Empire Logging Div.

Squamish, B.C.

Dr. A. Carlisle,

Petawawa Forest Expt. Station

Chalk River, Ont.

B. C. Goodell,

Faculty of Forestry,

U.B.C.

Vancouver, B.C.

J. Pleau,

9 Lessard,

Loretteville, Que.
J. E. Serveau,

Rm. 117 Bridges House,

University of New Brunswick Fredericton, N.B.

D. R. Parker,

87 Kelly's Mobilehome Crt.

RR \#3,

Fredericton, N.B.

Ronghui Ho,

2855 W. 14th. Ave.

Vancouver 8, B.C.

\section{STUDENT}

Susan Christy Corey, 516 Regent Station, Fredericton, N.B.

\section{AFFILIATE}

B. A. Coulcher, 9737 - 112 St. \#905,

Edmonton, Alta.

R. Raynauld, 909 Est. Mont Royal, Montreal 176, Que.

REINSTATED

E. J. Obdens,

22 Pearson St.

Saugus, Mass.

R. W. Nelson,

160 Blanchard St.

Port Arthur, Ont. 